Review

\title{
Formation and Change of Chloroplast-Located Plant Metabolites in Response to Light Conditions
}

\author{
Yiyong Chen ${ }^{1}$, Bo Zhou ${ }^{1}{ }^{\mathbb{D}}$, Jianlong $\mathrm{Li}^{1}{ }^{1}$, Hao Tang ${ }^{1}$, Jinchi Tang ${ }^{1, *}$ and Ziyin Yang ${ }^{2, *}$ \\ 1 Tea Research Institute, Guangdong Academy of Agricultural Sciences \& Guangdong Provincial Key \\ Laboratory of Tea Plant Resources Innovation and Utilization, Guangzhou 510640, China; \\ chenyiyong@gdaas.cn (Y.C.); zhoubo@gdaas.cn (B.Z.); Skylong.41@163.com (J.L.); \\ teaishealth@163.com (H.T.) \\ 2 Guangdong Provincial Key Laboratory of Applied Botany \& Key Laboratory of South China Agricultural \\ Plant Molecular Analysis and Genetic Improvement, South China Botanical Garden, Chinese Academy of \\ Sciences, Guangzhou 510650, China \\ * Correspondence: tangjinchi@126.com (J.T.); zyyang@scbg.ac.cn (Z.Y.); \\ Tel.: +86-20-8516-1049 (J.T.); +86-20-3807-2989 (Z.Y.)
}

Received: 26 January 2018; Accepted: 23 February 2018; Published: 26 February 2018

\begin{abstract}
Photosynthesis is the central energy conversion process for plant metabolism and occurs within mature chloroplasts. Chloroplasts are also the site of various metabolic reactions involving amino acids, lipids, starch, and sulfur, as well as where the production of some hormones takes place. Light is one of the most important environmental factors, acting as an essential energy source for plants, but also as an external signal influencing their growth and development. Plants experience large fluctuations in the intensity and spectral quality of light, and many attempts have been made to improve or modify plant metabolites by treating them with different light qualities (artificial lighting) or intensities. In this review, we discuss how changes in light intensity and wavelength affect the formation of chloroplast-located metabolites in plants.
\end{abstract}

Keywords: biosynthesis; chloroplast; light intensity; light wavelength; metabolite; photosynthesis

\section{Introduction}

Photosynthesis provides energy source for plant metabolism, and it represents an important photochemical reaction involving the trapping and conversion of energy from sunlight into biological energy in plants. Photosynthesis can be divided into two phases: one phase is the conversion of the photochemical energy from sunlight into biological energy, ATP and NADPH, and the other phase is the conversion of $\mathrm{CO}_{2}$ into carbon compounds using the biology energy. Chloroplasts are the organelles in which photosynthesis takes place in plants. Within chloroplasts, chlorophyll absorbs light, and the conversion of the light energy into biological energy is done on the photosynthetic electron transport chain (Calvin cycle). The biological energy is used in assimilatory reactions [1-3].

Many important metabolic reactions are taken place in chloroplasts, including the biosynthesis of partial amino acids, lipids and fatty acids, vitamins, and isoprenoids, and the reduction of nitrites and sulfates $[4,5]$. The transportation of the metabolites and messengers between plastids and cytosol are taken place on chloroplast envelopes [6,7]. Chloroplast envelopes contain two layers, the outside envelope which is closed to the cytosolic side, and the inner envelope. Several metabolites, such as lipids and pigments, are biosynthesized in the inner envelope membrane $[6,8,9]$, and chloroplast genome transcription and DNA replication are also implicated within the inner envelope [10]. The chloroplast stroma contains many enzymes, and the carbon assimilation and many biosynthetic processes are located on it. It also contains transcriptional and translational machinery. 
Light is one of the key environmental factors that influence the growth and development of the plants. Light energy is captured by photoreceptors in plants, and they are specialized pigment-protein complexes. They drive photosynthetic processes and respond to changes in light conditions (quality and quantity) through the responses of developmental and physiological known as photomorphogenesis [11,12]. Light also plays an important role in the accumulation of plant metabolite and the changes of morphological structure [13]. The biosynthesis of carbohydrates and some C-based defense compounds, for instance, terpenoids and phenols are affected by photosynthetic rates [14]. $\mathrm{N}$-containing plant secondary metabolites typically increase with decreasing light intensities [15]. However, in shade-tolerant plants, for example Tabernaemontana pachysiphon, N-based secondary metabolites were observed to accumulate extensively, but in some plant species demanding high light such as Rauvolfia vomitoria did not accumulate remarkably when photosynthesis decreased under low light intensities [16,17].

Light-emitting diode (LED) technology as a form of supplementation light source has made many advances in the regulation of plant metabolism. LEDs allow the control of light quality, quantity, and photoperiod for the regulation of plant metabolism. Until recently, many researches paid attention to the influence of LED light on the metabolites of vegetables and field crops, for instance lettuce [18,19], cucumber [20,21], tomato [22], radish, spinach [23], rice [24], and wheat [25]. Massa et al. [26] discussed the effect of LED light on plant yield, while Mitchell et al. [27] and Bergstrand et al. [28] reviewed the application status of LEDs and described the latest developments in greenhouse cultivation, respectively. Moreover, a large number of studies have evaluated the influence of light conditions on plant metabolites, which are mainly formed in chloroplasts [29-32]. However, few reviews have discussed the influence of light wavelength and intensity on metabolite accumulation in chloroplasts. Therefore, in the present article, we review the formation of chloroplast-located metabolites, and discuss how changes in light wavelength and intensity can affect their formation.

\section{Chloroplast-Located Metabolites}

\subsection{Carbohydrates}

Chloroplast is the organelle for photosynthetic carbon assimilation in plant cells. Carbohydrates assimilate in chloroplasts during the day, with some stored as starch, or degraded to supply sugars for growth at night. ATP and NADPH are produced in the photobiochemical process of photosynthesis, and are ultimately consumed in the assembly of $\mathrm{CO}_{2}$ into carbon compounds. Once $\mathrm{CO}_{2}$ is fixed by ribulose-1,5-bisphosphate carboxylase/oxygenase (Rubisco, EC 4.1.1.39), the product, 3-phosphoglyceric acid (3PGA), is catalyzed by a few reductive and regenerative enzymes and recycled the in the Calvin cycle (Figure 1). Some of reactions in it can be regulated by light, including the reductive activation catalyzed by the key enzymes such as sedoheptulose-1,7-bisphosphatase (FBPase), phosphoribulokinase (PRK), and glyceraldehyde 3-phosphate dehydrogenase (GAPDH) in the ferredoxin/thioredoxin system [33], and protein-protein interactions involving the reversible dissociation of GAPDH and PRK by CP12 ("chloroplast protein of $12 \mathrm{kDa}$ ") [34-38]. The enzymes that have been shown to be sensitive to light regulation are indicated in Figure 1A [39].

Starch is synthesized from intermediates of the Calvin cycle. When the rate of photosynthesis exceeds that of sucrose biosynthesis, up to $50 \%$ of recently assimilated $\mathrm{CO}_{2}$ is stored within the chloroplast as transitory starch. Sachs confirmed that under the condition of light and chlorophyll presence, starch within chloroplasts is directly derived from carbon fixation [40]. The rise in $\mathrm{pH}$ caused by light illumination in chloroplast stroma is advantageous for the synthesis of starch [41]. At high pH values, 3PGA is activated by pyrophosphorylase [42], while FBPase activity is enhanced which influences the proportion of carbon flowing through fructose-6-phosphate into starch [43]. In the following periods of darkness, transitory starch within chloroplasts is remobilized, and is used as a continuous carbon source for the development of sink organs and energy metabolism of leaves. 
As well as carrying out respiration in darkness, photorespiration is also exhibited in photosynthetic tissues, the light-dependent release of $\mathrm{CO}_{2}$, which is suggested to be tightly associated with the metabolism of glycolate, a $2 \mathrm{C}$ acid. Glycolate formation is a complex and irreversible process that cannot be uncoupled from photosynthetic carbon metabolism in intact systems. In chloroplasts, glyoxylate is reduced by NADPH-dependent glyoxylate reductase to form glycolate [44-46]. Light mainly influences glycolate formation by providing suitable substrates, and glycolate synthesis follows the light saturation curve for photosynthesis [47,48].

\subsection{Amino Acids}

The inorganic nitrogen is assimilated in plants and used to synthesize the 20 amino acids required for the biosynthesis of normal protein. Amino acid synthesis is closely associated with carbohydrate metabolism. Substrates for amino acid synthesis are mainly the intermediates of glycolysis, the citric acid cycle, and the pentose phosphate pathway. For example, aromatic amino acids such as phenylalanine, tyrosine, tryptophan, and histidine are synthesized from erythrose-4-phosphate and phosphoribosylpyrophosphate, which derive from the pentose phosphate pathway (Figure 1B). Phosphoenolpyruvate, one of the other substrates for aromatic amino acid synthesis, comes from glycolysis, while glycine, cysteine, and serine are synthesized from 3-phosphoglycerate, another intermediate of glycolysis. Aromatic amino acids are synthesized within chloroplasts, where ATP and the reductants needed for amino acid biosynthesis are derived [49], together with the essential amino acids [50]. The major metabolic reactions for the essential amino acids biosynthesis and the enzymes that catalyze the reactions are located within chloroplasts [51-53]. Oxaloacetate, one of the intermediates of citric acid cycle, is the substrate for synthesis of the aspartic acid derived amino acids asparagine, lysine, threonine, methionine, and isoleucine, while 2-oxo-glutarate is the initial substrate for the biosynthesis of glutamic acid, glutamine, proline, and arginine. Essential amino acids are synthesized from aromatic and aspartic acid derived amino acid pathways, which are the two most-studied pathways. The most part of the pathway for arginine synthesis is localized within the chloroplast, while some enzymes in the pathway are located in the cytosol [54]. Pyruvate is one of the substrates for the biosynthesis of branched-chain amino acids valine and leucine, as well as alanine. The biosynthesis of glutamine and asparagine, two amide amino acids, are tightly regulated by light. For instance, the expression of glutamine synthetase, one of the important enzymes for glutamine, is induced by light, while the asparagine synthetase genes are repressed by light [55].

\subsection{Lipids}

Chloroplasts contain a complex photosynthetic membrane system that dominates the total membrane content of leaves [56] and is the main location for lipid synthesis and assembly [57]. In thylakoids, the chloroplast-specific glycoglycerolipids monogalactosyldiacylglycerol, digalactosyldiacylglycerol, sulfoquinovosyldiacylglycerol, and phosphatidylglycerol construct a special hydrophobic matrix for pigment-protein complexes which are essential for photosynthesis. Some of the fatty acids synthesized in chloroplasts are directly assembled into thylakoid lipids, while others are exported to the endoplasmic reticulum (ER). Chloroplast lipid precursors originate from different locations, and are primarily assembled at the chloroplast envelope membranes [58]. All of the membrane lipids and storage lipids in plant, included fatty acids that derive from plastid-synthesized palmitic acid (16:0) and oleic acid (18:1) are biosynthesized in the chloroplasts stroma (Figure 1C) $[59,60]$. Once formed, one part of the fatty acids are directly synthesized into glycerolipids (galactolipids, sulfolipid, and phosphatidylglycerol) within the envelopes, while the other parts are exported across the envelopes to the ER in which they are constructed into phospholipids, especially phosphatidylcholine [61,62].

Light has been reported to greatly affect chloroplast acyl lipid metabolism. For example, the biosynthesis of the fatty acids is a light-dependent reaction because it needed the reducing power and ATP generated by photosynthesis [63]. Labeled carbon experiments suggested that the 
most possibility precursor for fatty acid biosynthesis in chloroplasts is pyruvate [64,65]. Acetyl-CoA carboxylase catalyzes the carboxylation of acetyl-CoA to malonyl-CoA in an ATP-dependent manner. $\mathrm{C} 2$ units derived from malonyl-CoA then build up 16C and 18C fatty acids. Because malonyl-CoA only functions in fatty acid biosynthesis within plastids, acetyl-CoA carboxylase is considered to be a committed enzyme in the reaction [66]. The extension of the fatty acid chain is catalyzed by a set of essential decentralized enzymes including fatty acid synthase, and all catalytic activities of the enzymes are required for acyl carrier protein. Figure $1 \mathrm{C}$ summarizes the formation of $16 \mathrm{C}$ and $18 \mathrm{C}$ fatty acids in chloroplasts.

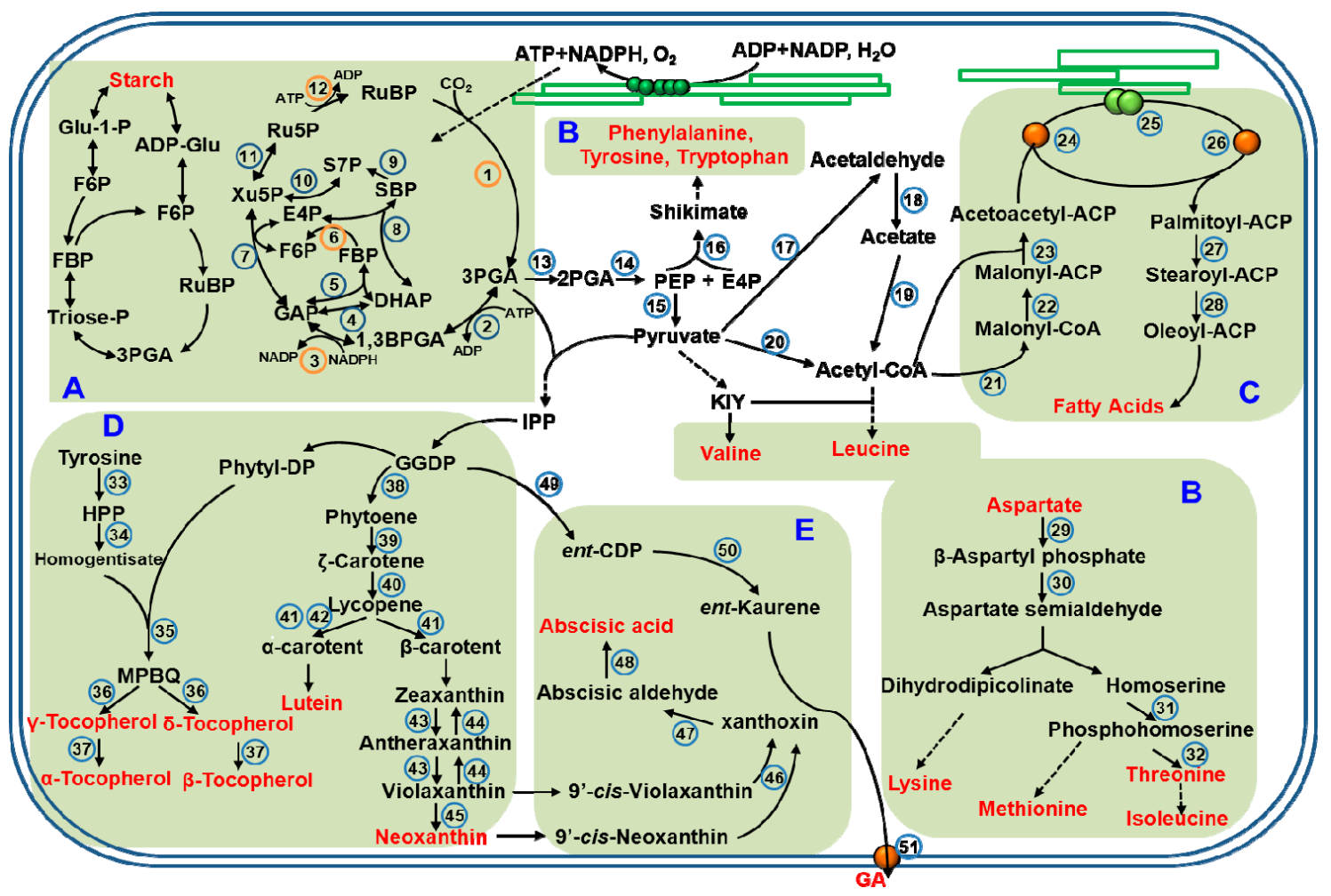

Figure 1. Schematic representation of biosynthetic pathways for the main metabolites in chloroplasts. (This figure is summarized based on review by Gontero et al., 2014 [39]; Joyard et al., 2010 [66]; Lancien et al., 2007 [53]; Kelly et al., 1976 [43]). Different regions represent different metabolite pathways, (A) Carbohydrates; (B) Amino acids; (C) Fatty acids; (D) Vitamins; (E) Hormones. The enzymes are indicated by number surrounded by a full circle, and orange circle represent sensitive to light-regulation $(1,3,6,9$ and 12). All the enzymes of these overlapping metabolic pathways are listed in the Table 1. Abbreviations: 2PGA, 2-phosphoglycerate; 3PGA, 3-phosphoglycerate; ACP, acyl-carrier protein; ADP, adenosine diphosphate; ADP-Glu, adenosine diphosphate glucose; ATP, adenosine triphosphate; BPGA: 1,3-bisphosphoglycerate; DHAP: dihydroxyacetone phosphate; E4P: erythrose-4-phosphate; ent-CDP, ent-copalyl diphosphate; F6P, fructose-6-phosphate; FBP: fructose-1,6-bisphosphate; GA, gibberellin; GAP: glyceraldehyde-3-phosphate; GGDP, geranylgeranyl diphosphate; Glu-1-P, glucose-1-phosphate; HPP, p-hydroxyphenylpyruvate; IPP, isopentenylpyrophosphate; KIY, $\alpha$-ketoisovalerate; NADH, nicotinamide adenine dinucleotide; MPBQ, methyl-6-phytyl-1,4-benzoquinone; NADPH, nicotinamide adenine dinucleotide phosphate; PEP, phosphoenolpyruvate; phytyl-DP, phytyl-diphosphate; Ru5P: ribulose-5-phosphate; RuBP: ribulose-1,5-bisphosphate; S7P: sedoheptulose-7-phosphate; SBP: sedoheptulose-1,7-bisphosphate; Triose-P, triose-phosphate; Xu5P: xylulose-5-phosphate. 
Table 1. List of the enzymes in metabolic pathways that are show in the Figure 1.

\begin{tabular}{|c|c|c|c|c|c|}
\hline No. & Enzyme & No. & Enzyme & No. & Enzyme \\
\hline 1 & $\begin{array}{c}\text { Ribulose-1,5-bisphosphate } \\
\text { carboxylase-oxygenase (RuBisco) }\end{array}$ & 18 & Aldehyde dehydrogenase & 35 & $\begin{array}{l}\text { Homogentisate phytyl } \\
\text { transferase }\end{array}$ \\
\hline 2 & Phosphoglycerate kinase & 19 & Acetyl-CoA synthetase & 36 & Tocopherol cyclase \\
\hline 3 & $\begin{array}{l}\text { Glyceraldehyde-3-phosphate } \\
\text { dehydrogenase }\end{array}$ & 20 & $\begin{array}{l}\text { Pyruvate dehydrogenase } \\
\text { complex }\end{array}$ & 37 & $\begin{array}{c}\gamma \gamma \text {-Tocopherol } \\
\text { methyltransferase (VTE4) }\end{array}$ \\
\hline 4 & Triose phosphate isomerase & 21 & Acetyl-CoA Carboxylase & 38 & Phytoene synthase \\
\hline 5 & Aldolase & 22 & ACP-s-malonyl transferase & 39 & Phytoene desaturase \\
\hline 6 & Fructose-1,6-bisphosphatase & 23 & $\begin{array}{c}\beta \text {-Ketoacyl-ACP synthase } \\
\text { KAS III }\end{array}$ & 40 & $\zeta$-Carotene desaturase \\
\hline 7 & Transketolase & 24 & 3-Oxoacyl-ACP-reductase & 41 & Lycopene $\beta$-cyclase \\
\hline 8 & Aldolase & 25 & $\begin{array}{l}\text { Hydroxyacyl-ACP } \\
\text { dehydrase }\end{array}$ & 42 & Lycopene $\varepsilon$-cyclase \\
\hline 9 & Sedoheptulose-1,7-bisphosphatase & 26 & 3-Enoyl-ACP-reductase & 43 & Zeaxanthin epoxidase \\
\hline 10 & Transketolase & 27 & $\begin{array}{c}\text { 3-Oxoacyl-ACP synthase } \\
\text { KASII }\end{array}$ & 44 & Violaxanthin de-epoxidase \\
\hline 11 & Xylulose-5-phosphate epimerase & 28 & Stearoyl-ACP desaturase & 45 & Neoxanthin synthase \\
\hline 12 & Phosphoribulokinase & 29 & Aspartate & 46 & $\begin{array}{l}\text { 9-Cis-epoxycarotenoid } \\
\text { dioxygenases (NCED) }\end{array}$ \\
\hline 13 & Phosphoglycerate & 30 & $\begin{array}{c}\text { Aspartate semialdehyde } \\
\text { dehydrogenase }\end{array}$ & 47 & Alcohol dehydrogenase \\
\hline 14 & Enolase & 31 & Homoserine kinase & 48 & Abscisic aldehyde oxidase \\
\hline 15 & Pyruvate kinase & 32 & Threonine synthase & 49 & $\begin{array}{l}\text { ent-Copalyl diphosphate } \\
\text { synthase }\end{array}$ \\
\hline 16 & $\begin{array}{l}\text { 3-Deoxy-D-arabino-heptulosonate-7- } \\
\text { phosphate synthase }\end{array}$ & 33 & Tyrosine amino transferase & 50 & ent-Kaurene synthase \\
\hline 17 & Pyruvate decarboxylase & 34 & $\begin{array}{l}\text { Hydroxyphenylpyruvate } \\
\text { (HPP) dioxygenase }\end{array}$ & 51 & ent-Kaurene oxidase \\
\hline
\end{tabular}

\subsection{Vitamins}

Some plant vitamins are biosynthesized in a restricted compartment. For instance, carotenoids such as pro-vitamin $\mathrm{A}$, vitamins $\mathrm{E}$ and $\mathrm{K} 1$, and water-soluble riboflavin are biosynthesized in the plastids [67-69]. Other vitamins, such as phylloquinone and riboflavin, are biosynthesized not uniformly distributed within plant tissue [70,71]. Carbohydrate metabolites are the main upstream precursors for most vitamins. The most abundant groups of lipid-soluble vitamins, carotenoids and tocopherols, are biosynthesized in partly or in whole pathway of isoprenoid biosynthetic pathway in plastid.

Carotenoids consist of a large isoprenoid family, most members in which are C40 tetraterpenoids, and phytoene is the substrate for them. Carotenoids can be classified as non-oxygenated and oxygenated, with the latter including xanthophylls. In some flowers and fruits, $\beta$-carotene in chloroplasts and lycopene in the chromoplasts are two of the most common non-oxygenated carotenoids. In plant photosynthetic tissues, light-harvesting complexes comprise the most abundant xanthophylls, for instance lutein, iolaxanthin and neoxanthin. Carotenoids are involved in a series of physiological process including the assembly of photosystem, light harvesting, photomorphogenesis, photoprotection, and nonphotochemical quenching [72-75]. Carotenoids also influence the size and function of the light-harvesting antenna.

The initial step of plant carotenoid synthesis is the conversion of two molecules of geranylgeranyl diphosphate (GGDP) to formation of phytoene, and the reaction is catalyzed by the enzyme phytoene synthase (Figure 1D). GGDP is considered to be a key intermediate in the pathway for carotenoids, tocochromanols, and many other plastidic isoprenoids biosynthesis [76]. Phytoene is produced as a 15-cis isomer, which can subsequently convert to all-trans isomer derivatives. Lycopene is biosynthesized from the desaturation of phytoene, the reactions are catalyzed by phytoene desaturase and $\zeta$-carotene desaturase, and the reaction also needed the plastid terminal oxidase 
and plastoquinone [77,78]. Lycopene is subsequently cyclized to synthesize $\alpha$-carotene and $\beta$-carotene, and then undergo a series of oxygenation reactions, xanthophylls are formed, which are typically found in chloroplasts. After lycopene synthesis, the pathway of carotenoid biosynthesis has two main branches. The difference of the two branches is the cyclic end groups. $\beta$-Carotene and its derivatives (zeaxanthin, violaxanthin, antheraxanthin, and neoxanthin) are biosynthesized from $\beta, \beta$ branch, which has two beta rings, whereas $\alpha$-carotene and its derivatives come from $\beta, \varepsilon$ branch, which is defined by one beta and one epsilon ring. The formation of $\alpha$-carotene and lutein require $\beta$-cyclase and $\varepsilon$-cyclase enzymes, respectively $[79,80]$.

Tocochromanols play an important role in the constitution of chloroplast membranes, and are only synthesized in photosynthetic organisms. Tocochromanols are a group of four tocopherols and four tocotrienols, which differ in the degree of methylation of the polar moiety. $\alpha-, \beta-$, $\gamma-$, and $\delta$-tocochromanols differ only in the number and position of methyl substituents on the aromatic ring. Tocopherols are identified by the phytyl-derived side chain of tocochromanols, while tocotrienols are identified by the geranylgeranyl-derived side chain. The polar moiety of tocochromanols derives from tyrosine, and the hydrophobic polyprenyl side chain originates from the isoprenoid pathway. All tocochromanol synthesis is initiated by p-hydroxyphenylpyruvic acid (HPP) dioxygenase which catalyzes the conversion of HPP into homogentisic acid (HGA). Then the pathway diverges at the step where a polyprenyl side chain is attached to HGA. Homogentisic acid phytyltransferase catalyzes the condensation of HGA and phytyl-diphosphate (phytyl-DP) (Figure 1) to form methyl-6-phytyl-1,4-benzoquinone (MPBQ), which is the committed intermediate of all tocopherols. The other diverged pathway involves the condensation of HGA and solanesyl-diphosphate to form 2-methyl-6-solanesyl-benzoquinol, the immediate precursor of plastoquinone-9. In plants, tocochromanols and the enzymes for their synthesis are localized in plastid membranes [81]. It has been reported that most tocopherols increase under high light stress [82].

\subsection{Hormones}

Abscisic acid (ABA) and gibberellin (GA) are two hormones synthesized in chloroplasts to support photosynthesis $[83,84]$. ABA is important for seed development and dormancy, as well as plays an important role in response when plants are exposed to environmental stresses. The synthesis and function of ABA are closely related to plastids. In plastids, zeaxanthin (ZEA) is the one of the first products of ABA biosynthesis, which derives from a common five-carbon (C5) precursor, isopentenyl. Pyruvate and glyceraldehyde 3-phosphate are two substrates for isopentenyl diphosphate synthesis, and the intermediate, 2-C-methyl-D-erythritol-4-phosphate (MEP) is key production in the pathway, which is so called MEP pathway. The other pathway for isopentenyl diphosphate is the mevalonic acid pathway, which is located in the cytosol [85]. The biosynthesis of plastidic isoprenoids, including carotenoids, originates from the MEP pathway $[86,87]$. With the catalysis of zeaxanthin epoxidase, ZEA is then transformed into violaxanthin, and antheraxanthin is the intermediate. The pathway from violaxanthin to neoxanthin synthesis has not been elucidated completely. After the generation of xanthoxin, it is transported into the cytosol and oxidized to form ABA aldehyde, and finally synthesize ABA [88]. Photo-induced ABA signaling can regulate the expression of several thousand nuclear genes [89].

GAs are another important hormones, which are essential for multiple processes in the life cycle of higher plants, and it controls plant growth and development [90]. The substrate for GAs biosynthesis is the geranylgeranyl diphosphate (GGDP), which is also an intermediate of carotenoid synthesis, and it is a common C20 precursor for diterpenoids. Terpene synthases (TPSs), cytochrome P450 monooxygenases (P450s), and 2-oxoglutarate-dependent dioxygenases are three different classes of important enzymes, which are required for the transform of GGDP into GAs. ent-Kaurene synthase and ent-copalyl diphosphate synthase are two TPSs, located in the plastids, and they are key enzymes in the formation of tetracyclic hydrocarbon intermediate ent-kaurene [91-93]. ent-Kaurenoic acid is produced by the oxidized of the C-19 on the ent-kaurene, and the reaction is catalyzed by ent-kaurene 
oxidase (KO). ent-Kaurenoic acid is sequentially converted to GA12 by ent-kaurenoic acid oxidase (KAO) [94]. Experiments have confirmed that $\mathrm{KO}$ is present in the outer envelope of chloroplast, whereas $\mathrm{KAO}$ is located in the ER (Figure 1E) [92].

\subsection{Secondary Metabolites}

Primary metabolites, such as amino acids, lipids, nucleotides, and so on usually play essential and evident metabolic roles in all plants. While the secondary metabolites, such as terpenoids, phenolic compounds and alkaloids, may not directly participate in plant growth and development [95]. Phenolic compounds are primarily biosynthesized from intermediate of the shikimic acid pathway, and alkaloids are principally biosynthesized from the branch pathway of amino acids. Isoprene, the prime substrate of terpenoids, is produced in plastids. However, sesquiterpenes, triterpenes, and polyterpenes are synthesized in cytosolic and endoplasmic reticulum. It is considered that terpenoids may be the most structurally varied class of plant secondary metabolites. The $5 \mathrm{C}$ units of terpenoids can be synthesized by two pathways, acetate/mevalonate pathway or the glyceraldehyde 3-phosphate/pyruvate pathway. In plastids, isopentenyldiphosphate (IPP), which is the precursor for all terpenoidsis, is synthesized from the pathway of glyceraldehyde 3-phosphate/pyruvate [95]. In this pathway, hydroxyethyl- thiamine pyrophosphate (TPP) is produced by the reaction of pyruvate and TPP, and then condenses with glyceraldehyde 3-phosphate. TPP is released to form 1-deoxy-D-xylulose 5-phosphate. Sunlight is one of the most important environmental factors regulating the accumulation of secondary metabolite [96].

\section{Light Conditions Affect Chloroplast-Located Metabolites in Plants}

\subsection{Light Wavelength Affects Chloroplast-Located Metabolites}

Light is one of the most important factors which influence plant metabolite production $[97,98]$. Light parameters, such as light wavelength, light fluence rate, and photoperiod, affect photosynthesis in plants [99,100]. Plant physiological changes can be triggered by varying light wavelengths [101], and the accumulation of phytochemical metabolites are positively affected by light intensity [102]; however, the effects of light quality are more complex. For example, anthocyanins can be increased by blue light in tomato [103], and by UV-A induction in grape [104] and lettuce [105]. However, in cranberry fruits, anthocyanin production seems most responsive to red light [106]. Moreover, blue light can increase the levels of carotenoids in coffee [107] and ascorbic acid in lettuce and komatsuna, however it has no effect in spinach [32]. These results show that the phytochemical concentration is increased by optimizing light quality. Many studies have focused on red and blue light for the reason that the spectra of them are most important for driving photosynthesis [32,106]. Red light induces transformations in the phytochrome system [108], and blue light affects the formation of chlorophyll, stomatal opening, and photomorphogenesis [109-111]. LEDs can be designed to provide different light qualities based on the requirements of plant growth and development [112].

The influence of the light wavelength on plant is not only limited to the development and the growth. Recent researches have confirmed that light qualities affect the levels of pigments and metabolites, for instance carbohydrates, amino acids, carotenoids, anthocyanins, fatty acids, and nitrates (Table 2). The conversion of $\mathrm{CO}_{2}$ to carbohydrates involves a sequence of light-independent and enzymatic catalytic reactions, but the biosynthesis and accumulation of carbohydrates and proteins are significantly influenced by light qualities. Two major driving photosynthetic biosynthesis lights, red light and blue light are effective at increasing soluble sugar and protein. Many researchers have demonstrated that the soluble sugar content in the seedlings of cucumber, tomato, and radish can be increased by red LED light [113]. In pea seedlings, the levels of soluble sugar can also be markedly increased by red light, whereas the biosynthesis of soluble proteins was significantly restricted [114]. Compared with other types of LED light, blue LED light led to the higher soluble sugar accumulation in tomato seedlings, whereas the level of soluble proteins was highest under a mixture light of red 
and blue LED [115]. Blue light has also been shown to facilitate protein biosynthesis, and can prevent protein degeneration [116]. During plant growth, blue light exposure is qualitatively required for normal photosynthesis [29].

Plant pigments, chlorophyll and carotenoid, are function in plant light harvesting and photoprotection. Light wavelengths have different effects on these two pigments because their maximum absorptions differ. In the visible light spectrum, the maximum absorption of chlorophyll a and $\mathrm{b}$ in the red region is 663 and $642 \mathrm{~nm}$, respectively, and 430 and $453 \mathrm{~nm}$, respectively, in the blue regions. Lutein and $\beta$-carotene, which are two carotenoid pigments, have their highest absorption in the blue region at 448 and $454 \mathrm{~nm}$, respectively [117]. It has been reported that total chlorophyll and carotenoid levels were accumulate in white or blue light, but were lower after exposure to red light alone. Compared with white or monochromatic blue light, a mixture of blue LEDs and red LEDs induced higher accumulation of carotenoid levels, whereas carotenoid levels decreased in red light alone. Blue light also increases the accumulation of $\beta$-carotene and violaxanthin carotenoid levels [98]. In blue light-activated stomatal operations, zeaxanthin is an important photoreceptor that modulates blue light-dependent responses in plants [118,119].

Light quality also affects the fatty acid profile. Red light promotes the lipid content, and fatty acids can be induced by narrow bandwidth blue light [120]. Compared with other light wavelength treatments of algae, green light significantly increased the concentration of hexadecatrienoic acid (16:3) and resulted in the highest content of $\alpha$-linolenic acid (18:3), while the concentrations of stearic acid (18:0), oleic acid (18:1), and linolenic acid (18:2) were significantly decreased [121]. In plants and green algae such as Chlorella vulgaris, hexadecatrienoic acid (16:3) and $\alpha$-linolenic acid (18:3) are present in high concentrations in the thylakoid membranes of chloroplasts [121,122]. Because the absorbance of light at a green wavelength is low, the increased proportion of fatty acids together with increases in the number of chloroplasts and/or thylakoid structure rearrangements could compensate for it.

Differences in light quality produce relatively large changes in amino acid levels. Blue light has been shown to enhance the amino acid content, with maize grown under blue light found to have substantially higher amino acid content than that grown under red light or in the dark [120]. Moreover, amino acid production was induced by narrow bandwidth blue light in rice seedling leaves exposed to different LED sources for seven days [123]. UV-B is another light source that regulates the amino acid content. In Arabidopsis, UV-B treatment moderately increased the glutamate and $\gamma$-amino butyrate content, and dramatically increased that of glutamine and histidine; while the content of these amino acids was unchanged under continuous light conditions. Oxaloacetate- and pyruvate-derived amino acids were also discovered to be changed under the UV-B stress. The lysine content was moderately increased after extending the light period, but dramatically increased following UV-B stress [124]. Other amino acids, such as asparagine, aspartate, and threonine show similar phenomena [124].

Plant hormones such as GA, auxin, cytokinin, brassinolide, and ethylene play an import role in light-regulated development [125]. ABA synthesized from carotenoids is active throughout the development of plant and the responses for stress, and GAs are important in light-regulated seedling development [126]. Light-dependent processes, such as seed germination, photomorphogenesis during de-etiolation, and the photoperiod regulation of stem elongation and flowering are regulated at least in part by GA concentrations. Light, specifically red light, is sensed by phytochromes, and induces seed germination [127]. The GA4 content in seeds can be increased by light treatments which activate phytochromes, elevate the expression of $A t G A 3 o x 1$ and $A t G A 30 x 2$, and suppress that of AtGA2ox2 [128-130]. The expression of AtGA20ox1 and AtGA3ox1 genes is downregulated by blue light, which induces $A t G A 20 x 1$ expression. These transcriptional changes correlate with a cry-dependent transient decrease in GA4 levels after exposure to blue light [131,132].

\subsection{Light Intensity Affects Chloroplast-Located Metabolites}

The redox state of the photosynthetic electron transport chain is acutely sensitive to fluctuations in light intensity. Light activates a number of biosynthetic enzymes and inhibits glucose-6-phosphate 
dehydrogenase in carbohydrate degradation. The oxidation of plastoquinol to plastoquinone and the reduction of thioredoxin are favored under low light conditions, while the reverse occurs at higher irradiance [133]. In darkness, this process is fully reversed by oxygen. However, very high light intensity represents an abiotic stress factor for plants, because it may induce secondary destructive processes of photosynthesis. In Arabidopsis, the content of most metabolites in glycolysis and the oxidative pentose phosphate pathway were altered when leaves were exposed to high light for six days. This indicated that plants undergo a metabolic shift with high light exposure. Additionally, an increase in the Calvin cycle fixed more carbon, while the activation of photorespiratory pathways was indicated by increased glycine content [134]. The photorespiratory intermediates glycine and glycolate were observed to accumulate in the early phase (5-60 min after transition) of high light stress [135]. Plant photosynthesis can also be damaged by strong UV-B radiation. Under this condition, the activity and content of Rubisco [136] and sedoheptulose 1,7-biphosphatase are both lost [137], while the photosynthetic electron transport chain is inactivated [138], and stomatal closure occurs [139].

The light intensity plays important role in chlorophyll biosynthesis. For instance, Tripathy \& Brown found the result that chlorophyll was accumulated in wheat seedlings under red LED light at $100 \mathrm{mmol} \mathrm{m}^{-2} \mathrm{~s}^{-1}$, but not at $500 \mathrm{mmol} \mathrm{m}^{-2} \mathrm{~s}^{-1}$ [140]. In tea leaves, volatile component, for example phenylpropanoids/benzenoids, and some amino acids like L-phenylalanine are increased in darkness induced re-etiolation [141], and the result suggesting the activation of a plastid-located shikimate pathway [142]. We previously showed that most amino acids, including L-phenylalanine, were present at higher levels in dark-treated tealeaves compared with those exposed to light. Our results show that the accumulation of free amino acids in dark-treated tealeaves resulted from the proteolysis of chloroplast proteins rather than the activation of amino acid biosyntheses [143].

The impact of light intensity on allocation to starch is less clear. In Lolium and Sorghum, high light increased the allocation to starch [144], while starch synthesis raised linearly with the photosynthetic rate at higher irradiance in Phaseolus vulgaris, but was negligible at very low irradiance [145]. Britz et al. compared soybean starch across a set of natural light regimes at different times of the year, revealing that starch allocation under natural light regimes was inversely related to photoperiod duration and peak irradiance [146]. Lutein and $\beta$-carotene are key components of the light-harvesting complex of leaves, and lutein is important to the plant photoprotection system under high light stress. Niyogi et al. observed photobleachin $g$ and leaf senescence in the absence of lutein under high light intensity [147].

Table 2. List of chloroplast-located plant metabolites in response to different light conditions. Ref., reference. " + ", represents that the metabolites level increased; "-" , represents that the metabolites level decreased.

\begin{tabular}{|c|c|c|c|c|}
\hline Metabolites & Light Conditions & Species & Effects & Ref. \\
\hline \multirow{7}{*}{ Soluble sugar } & Red light & $\begin{array}{c}\text { Lettuce; Broccoli; Cabbage; } \\
\text { Mustard; Parsley; Maize; Rice }\end{array}$ & + & {$[97]$} \\
\hline & Red light & Radish & + & [113] \\
\hline & Red light & Pea seedlings & + & [115] \\
\hline & Blue light & Spinach; Maize; Cabbage; & + & [97] \\
\hline & Blue light & Tomato & + & [115] \\
\hline & High light intensity & Turnip & + & [97] \\
\hline & Dark & $\begin{array}{c}\text { Lettuce; Spinach; Broccoli; } \\
\text { Kale; Maize }\end{array}$ & - & [97] \\
\hline \multirow{2}{*}{ Starch } & High light intensity & Lolium; Sorghum & + & [144] \\
\hline & High light intensity & Phaseolus vulgaris & + & [145] \\
\hline Glycolate & High light intensity & Arabidopsis thaliana & + & [135] \\
\hline \multirow{4}{*}{ Amino acids } & Blue light & Maize & + & [120] \\
\hline & Narrow bandwidth blue light & Rice & + & [123] \\
\hline & UV-B & Arabidopsis thaliana & + & [124] \\
\hline & Dark & Camellia sinensis & + & {$[141,143]$} \\
\hline
\end{tabular}


Table 2. Cont.

\begin{tabular}{|c|c|c|c|c|}
\hline Metabolites & Light Conditions & Species & Effects & Ref. \\
\hline Glycine & High light intensity & Arabidopsis thaliana & + & [134] \\
\hline Phenylpropanoids/Benzenoids & Dark & Camellia sinensis & + & [141] \\
\hline \multirow{2}{*}{ Protein } & Red light & Pea & - & [114] \\
\hline & A mixture of red and blue light & Tomato & + & [115] \\
\hline Lipid & Red light & Maize & + & [120] \\
\hline Fatty acids & Narrow bandwidth blue light & Maize & + & [120] \\
\hline Hexadecatrienoic acid & Green light & Chlorella vulgaris & + & [122] \\
\hline$\alpha$-Linolenic acid & Green light & Chlorella vulgaris & + & [122] \\
\hline Lutein & High light intensity & Arabidopsis thaliana & - & [147] \\
\hline \multirow{5}{*}{ Carotenoids } & Red light & Lettuce; Kale; Tomato & + & [97] \\
\hline & Red light & Lettuce & - & [97] \\
\hline & Blue light & Coffee & + & [107] \\
\hline & Blue light & Spinach; Broccoli & + & [97] \\
\hline & Dark & Kale & & [97] \\
\hline$\beta$-Carotene and violaxanthin & Blue light & Broccoli & + & [98] \\
\hline Zeaxanthin & Blue light & Lemna trisulca & + & [119] \\
\hline \multirow{2}{*}{ GA } & Red light & Arabidopsis thaliana & + & [128-130] \\
\hline & Blue light & Arabidopsis thaliana & - & {$[131,132]$} \\
\hline \multirow{4}{*}{ Anthocyanins } & Blue light & Tomato & + & [103] \\
\hline & UV-A & Grape & + & [104] \\
\hline & UV-A & Lettuce & + & [105] \\
\hline & Red light & Cranberry & + & [106] \\
\hline
\end{tabular}

\section{Conclusions}

In this review, we summarize the biosynthesis of main chloroplast-located metabolites, carbohydrates, amino acids, lipids, vitamins, and hormones. These metabolites are essential for plant physiological process. Photosynthesis represents one of the most important photochemical reactions for the metabolites biosynthesis in plants, because it's the central energy conversion process for plant metabolism. Light is the crucial environmental factor to plant photosynthesis. Light conditions, such as light quality and light intensity, can affect the level of plant metabolites. Many attempts have been made to improve or modify plant metabolites by treating them with different light qualities (artificial lighting) or intensities. This review also discusses how plant metabolites affected by changes in light intensity and wavelength.

Acknowledgments: A part of the research aspects done by the authors are supported by the financial supports from the National Key Research and Development Project of China (2016YFD0200900), the National Natural Science Foundation of China (31600559), the Guangdong Innovation Team of Modern Agricultural Industry Technology System (2017LM1092), the Natural Science Foundation of Guangdong (2016A030313773 and 2016A030306039), the Construction of Industrial Technology Innovation Platform for Black Tea of Guangdong Big Leaves Species, the Foundation of Science and Technology Program of Guangzhou, and , the Guangdong Special Support Plan for Training High-Level Talents (2016TQ03N617). Because of space limitations, we could not cite all publications in the field; we apologize to all colleagues whose work has not been mentioned.

Author Contributions: Ziyin Yang, Jinchi Tang constructed the manuscript outline; Yiyong Chen, Bo Zhou, Jianlong $\mathrm{Li}$, Hao Tang wrote the manuscript; all authors read and approved the final manuscript.

Conflicts of Interest: The authors declare no conflict of interest.
Abbreviations
3PGA 3-Phosphoglyceric acid
ABA Abscisic acid
ER Endoplasmic reticulum
FBPase Sedoheptulose-1,7-bisphosphatase 


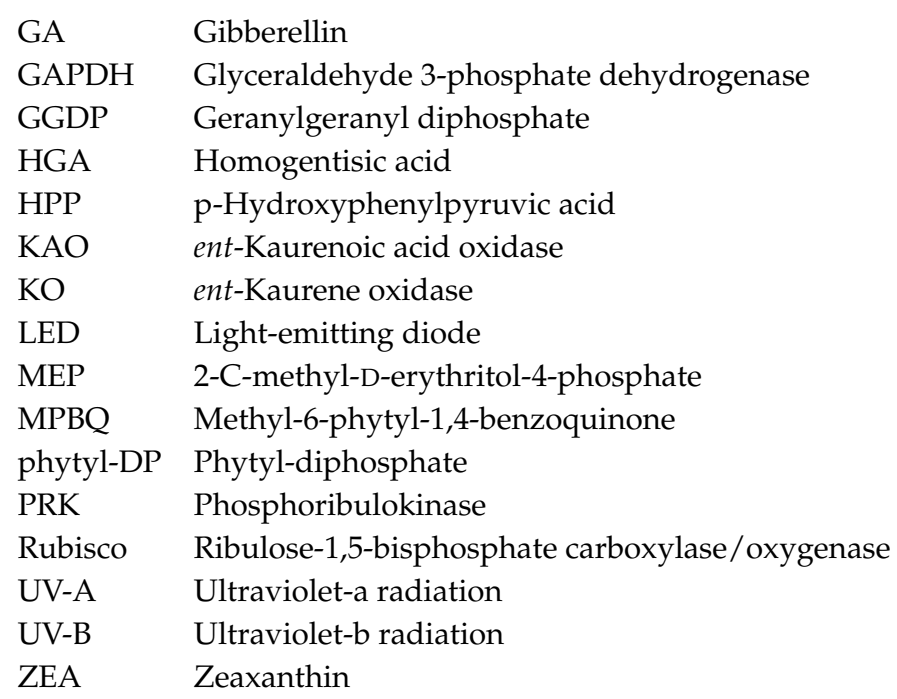

\section{References}

1. Pego, J.V.; Kortstee, A.J.; Huijser, C.; Smeekens, S.C.M. Photosynthesis, sugars and the regulation of gene expression. J. Exp. Bot. 2000, 51, 407-416. [CrossRef] [PubMed]

2. Eberhard, S.; Finazzi, G.; Wollman, F.A. The dynamics of photosynthesis. Annu. Rev. Genet. 2008, 42, 463-515. [CrossRef] [PubMed]

3. Foyer, C.H.; Neukermans, J.; Queval, G.; Noctor, G.; Harbinson, J. Photosynthetic control of electron transport and the regulation of gene expression. J. Exp. Bot. 2012, 63, 1637-1661. [CrossRef] [PubMed]

4. Van Wijk, K.J. Proteomics of the chloroplast: Experimentation and prediction. Trends Plant Sci. 2000, 5, 420-425. [CrossRef]

5. Baginsky, S.; Gruissem, W. Chloroplast proteomics: Potentials and challenges. J. Exp. Bot. 2004, 55, 1213-1220. [CrossRef] [PubMed]

6. Joyard, J.; Teyssier, E.; Miège, C.; Berny-Seigneurin, D.; Maréchal, E.; Block, M.A.; Dorne, A.J.; Rolland, N.; Ajlani, G.; Douce, R. The biochemical machinery of plastid envelope membranes. Plant Physiol. 1998, 118, 715-723. [CrossRef] [PubMed]

7. Soll, J.; Tien, R. Protein translocation into and across the chloroplastic envelope membranes. Plant Mol. Biol. 1998, 38, 191-207. [CrossRef] [PubMed]

8. Maréchal, E.; Block, M.A.; Dorne, A.J.; Douce, R.; Joyard, J. Lipid synthesis and metabolism in the plastid envelope. Physiol. Plant. 1997, 100, 65-77. [CrossRef]

9. Bruce, B.D. The role of lipids in plastid protein transport. Plant Mol. Biol. 1998, 38, 223-246. [CrossRef] [PubMed]

10. Sato, N.; Rolland, N.; Block, M.A.; Joyard, J. Do plastid envelope membranes play a role in the expression of the plastid genome? Biochimie 1999, 81, 619-629. [CrossRef]

11. Smith, H. Light quality, photoperception, and plant strategy. Annu. Rev. Plant Physiol. 1982, 33, 481-518. [CrossRef]

12. Christie, J.M. Phototropin blue-light receptors. Annu. Rev. Plant Biol. 2007, 58, 21-45. [CrossRef] [PubMed]

13. Theis, N.; Lerdau, M. The evolution of function in plant secondary metabolites. Int. J. Plant Sci. 2003, 164, 93-102. [CrossRef]

14. Bryant, J.P.; Chapin, F.S., III; Klein, D.R. Carbon/nutrient balance of boreal plants in relation to vertebrate herbivory. Oikos 1983, 357-368. [CrossRef]

15. Coelho, G.C.; Rachwal, M.F.; Dedecek, R.A.; Curcio, G.R.; Nietsche, K.; Schenkel, E.P. Effect of light intensity on methylxanthine contents of Ilex paraguariensis A. St. Hil. Biochem. Syst. Ecol. 2007, 35, 75-80. [CrossRef]

16. Höft, M.; Verpoorte, R.; Beck, E. Growth and alkaloid patterns of roots of Tabernaemontana pachysiphon and Rauvolfia mombasiana as influenced by environmental factors. Plant Biol. 1998, 111, 222-230.

17. Cai, Z.Q.; Wang, W.H.; Yang, J.; Cai, C.T. Growth, photosynthesis and root reserpine concentrations of two Rauvolfia species in response to a light gradient. Ind. Crop. Prod. 2009, 30, 220-226. [CrossRef]

18. Zhou, W.L.; Liu, W.K.; Yang, Q.C. Reducing nitrate concentration in lettuce by pre-harvest continuous light delivered by red and blue light-emitting diodes. J. Plant Nutr. 2013, 36, 481-490. 
19. Martineau, V.; Lefsrud, M.; Naznin, M.T.; Kopsell, D.A. Comparison of light-emitting diode and high-pressure sodium light treatments for hydroponics growth of Boston lettuce. Hortscience 2012, 47, $477-482$.

20. Wang, H.; Gu, M.; Cui, J.; Shi, K.; Zhou, Y.; Yu, J. Effects of light quality on $\mathrm{CO}_{2}$ assimilation, chlorophyll-fluorescence quenching, expression of Calvin cycle genes and carbohydrate accumulation in Cucumis sativus. J. Photochem. Photobiol. B. 2009, 96, 30-37. [CrossRef] [PubMed]

21. Wang, H.; Jiang, Y.; Shi, K. Effects of light quality on leaf senescence and activities of antioxidant enzymes in cucumber plants. Agric. Sci. Sin. 2010, 43, 529-534.

22. Liu, X.Y.; Xu, Z.G.; Chang, T.T.; Guo, S.R. Growth and photosynthesis of cherry tomato seedling exposed to different low light of LED light quality. Acta. Bot. Boreal-Occident Sin. 2010, 30, 725-732.

23. Samuolienè, G.; Sirtautas, R.; Brazaitytè, A.; Sakalauskaitè, J.; Sakalauskienè, S.; Duchovskis, P. The impact of red and blue light-emitting diode illumination on radish physiological indices. Open Life Sci. 2011, 6, 821-828. [CrossRef]

24. Matsuda, R.; Ohashi-Kaneko, K.; Fujiwara, K.; Goto, E.; Kurata, K. Photosynthetic characteristics of rice leaves grown under red light with or without supplemental blue light. Plant Cell Physiol. 2004, 45, 1870-1874. [CrossRef] [PubMed]

25. Sood, S.; Gupta, V.; Tripathy, B.C. Photoregulation of the greening process of wheat seedlings grown in red light. Plant Mol. Biol. 2005, 59, 269-287. [CrossRef] [PubMed]

26. Massa, G.D.; Kim, H.H.; Wheeler, R.M.; Mitchell, C.A. Plant productivity in response to LED lighting. HortScience 2008, 43, 1951-1956.

27. Mitchell, C.A.; Both, A.J.; Bourget, C.M.; Burr, J.F.; Kubota, C.; Lopez, R.G.; Morrow, R.C.; Runkle, E.S. Horticultural science focus-LEDs: The future of greenhouse lighting. Chron. Hort. 2012, 52, 6-10.

28. Bergstrand, K.J.; Schüssler, H. Recent progresses on the application of leds in the horticultural production. In Proceedings of the XXVIII International Horticultural Congress on Science and Horticulture for People (IHC2010): International Symposium on 927, Lisbon, Portugal, 28 February 2012; Castilla, N., Kooten, O., Sase, S., Meneses, F., Schnitzler, W., Van Os, E., Eds.; ISHS: Lisboa, Belgium, 2012; pp. 529-534.

29. Hogewoning, S.W.; Trouwborst, G.; Maljaars, H.; Poorter, H.; van Ieperen, W.; Harbinson, J. Blue light dose-responses of leaf photosynthesis, morphology, and chemical composition of cucumis sativus grown under different combinations of red and blue light. J. Exp. Bot. 2010, 61, 3107-3117. [CrossRef] [PubMed]

30. Li, Q.; Kubota, C. Effects of supplemental light quality on growth and phytochemicals of baby leaf lettuce. Environ. Exp. Bot. 2009, 67, 59-64. [CrossRef]

31. Samuolienè, G.; Sirtautas, R.; Brazaitytė, A.; Duchovskis, P. LED lighting and seasonality effects antioxidant properties of baby leaf lettuce. Food Chem. 2012, 134, 1494-1499. [CrossRef] [PubMed]

32. Ohashi-Kaneko, K.; Takase, M.; Kon, N.; Fujiwara, K.; Kurata, K. Effect of light quality on growth and vegetable quality in leaf lettuce, spinach and komatsuna. Environ. Control Biol. 2007, 45, 189-198. [CrossRef]

33. Schurmann, P.; Buchanan, B.B. The ferredoxin/thioredoxin system of oxygenic photosynthesis. Antioxid. Redox Sign. 2008, 10, 1235-1273. [CrossRef] [PubMed]

34. Howard, T.P.; Metodiev, M.; Lloyd, J.C.; Raines, C.A. Thioredoxin-mediated reversible dissociation of a stromal multiprotein complex in response to changes in light availability. Proc. Natl. Acad. Sci. USA 2008, 105, 4056-4061. [CrossRef] [PubMed]

35. Graciet, E.; Lebreton, S.; Gontero, B. Emergence of new regulatory mechanisms in the Benson-Calvin pathway via protein-protein interactions: A glyceraldehyde-3-phosphate dehydrogenase/CP12/phosphoribulokinase complex. J. Exp. Bot. 2004, 55, 1245-1254. [CrossRef] [PubMed]

36. Marri, L.; Trost, P.; Pupillo, P.; Sparla, F. Reconstitution and properties of the recombinant glyceraldehyde-3phosphate dehydrogenase/CP12/phosphoribulokinase supramolecular complex of Arabidopsis. Plant Physiol. 2005, 139, 1433-1443. [CrossRef] [PubMed]

37. Marri, L.; Trost, P.; Trivelli, X.; Gonnelli, L.; Pupillo, P.; Sparla, F. Spontaneous assembly of photosynthetic supramolecular complexes as mediated by the Intrinsically Unstructured Protein CP12. J. Biol. Chem. 2008, 283, 1831-1838. [CrossRef] [PubMed]

38. Tamoi, M.; Miyazaki, T.; Fukamizo, T.; Shigeoka, S. The Calvin cycle in cyanobacteria is regulated by CP12 via the $\mathrm{NAD}(\mathrm{H}) / \mathrm{NADP}(\mathrm{H})$ ratio under light/dark conditions. Plant J. 2005, 42, 504-513. [CrossRef] [PubMed]

39. Gontero, B.; Salvucci, M.E. Regulation of photosynthetic carbon metabolism in aquatic and terrestrial organisms by Rubisco activase, redox-modulation and CP12. Aquat. Bot. 2014, 118, 14-23. [CrossRef] 
40. Sachs, J. Über den Einfluß des Lichtes auf die Bildung des Amylums in den Chlorophyllkörnern. Bot. Z. 1862, 20, 365-373.

41. Heldt, H.W.; Werdan, K.; Milovancev, M.; Geller, G. Alkalization of the chloroplast stroma caused by light-dependent proton flux into the thylakoid space. BBA-Bioenergetics 1973, 314, 224-241. [CrossRef]

42. Ghosh, H.P.; Preiss, J. Adenosine diphosphate glucose pyrophosphorylase a regulatory enzyme in the biosynthesis of starch in spinach leaf chloroplasts. J. Biol. Chem. 1966, 241, 4491-4504. [PubMed]

43. Kelly, G.J.; Latzko, E.; Gibbs, M. Regulatory aspects of photosynthetic carbon metabolism. Ann. Rev. Plant Physiol. 1976, 27, 181-205. [CrossRef]

44. Kearney, P.C.; Tolbert, N.E. Appearance of glycolate and related products of photosynthesis outside of chloroplasts. Arch. Biochem. Bioph. 1962, 98, 164-171. [CrossRef]

45. Zelitch, I.; Gotto, A.M. Properties of a new glyoxylate reductase from leaves. Biochem. J. 1962, 84, 541-546. [CrossRef] [PubMed]

46. Tolbert, N.E.; Yamazaki, R.K.; Oeser, A. Localization and properties of hydroxypyruvate and glyoxylate reductases in spinach leaf particles. J. Biol. Chem. 1970, 245, 5129-5136. [PubMed]

47. Tolbert, N.E. Glycolate biosynthesis. In Current Topics in Cellular Regulation; Horecker, B.L., Stadtman, E.R., Eds.; Academic Press: New York, NY, USA, 1973; pp. 21-29.

48. Gibbs, M. Biosynthesis of glycolic acid. In Photosynthesis and Photorespiration; Wiley \& Sons Inc.: New York, NY, USA; London, UK; Sydney, Australia; Toronto, ON, Canada, 1971; pp. 433-441.

49. Maeda, H.; Dudareva, N. The shikimate pathway and aromatic amino acid biosynthesis in plants. Annu. Rev. Plant Biol. 2012, 63, 73-105. [CrossRef] [PubMed]

50. Reyes-Prieto, A.; Moustafa, A. Plastid-localized amino acid biosynthetic pathways of Plantae are predominantly composed of non-cyanobacterial enzymes. Sci. Rep. 2012, 2, 955. [CrossRef] [PubMed]

51. Binder, S. Branched-chain amino acid metabolism in Arabidopsis thaliana. In The Arabidopsis Book 8; The American Society of Plant Biologists: Rockville, MD, USA, 2010; pp. 1-14.

52. Jander, G.; Joshi, V. Recent progress in deciphering the biosynthesis of aspartate-derived amino acids in plants. Mol. Plant 2010, 3, 54-65. [CrossRef] [PubMed]

53. Lancien, M.; Lea, P.J.; Azevedo, R.A. Amino acid synthesis in plastids. In The Structure and Function of Plastids; Springer: Berlin/Heidelberg, Germany, 2007; pp. 355-385.

54. Slocum, R.D. Genes, enzymes and regulation of arginine biosynthesis in plants. Plant Physiol. Biochem. 2005, 43, 729-745. [CrossRef] [PubMed]

55. Oliveira, I.C.; Brenner, E.; Chiu, J.; Hsieh, M.H.; Kouranov, A.; Lam, H.M.; Shin, M.J.; Coruzzi, G. Metabolite and light regulation of metabolism in plants: Lessons from the study of a single biochemical pathway. Braz. J. Med. Biol. Res. 2001, 34, 567-575. [CrossRef] [PubMed]

56. Harwood, J.L. Lipid metabolism. CRC Crit. Rev. Plant Sci. 1989, 8, 1-43. [CrossRef]

57. Browse, J.; Somerville, C. Glycerolipid synthesis: Biochemistry and regulation. Ann. Rev. Plant Physiol. 1991, 42, 467-506. [CrossRef]

58. Wang, Z.; Benning, C. Chloroplast lipid synthesis and lipid trafficking through ER-plastid membrane contact sites. Biochem. Soc. Trans. 2012, 40, 457-463. [CrossRef] [PubMed]

59. Slabas, A.R.; Fawcett, T. The biochemistry and molecular biology of plant lipid biosynthesis. Plant Mol. Biol. 1992, 19, 169-191. [CrossRef] [PubMed]

60. Harwood, J.L. Recent advances in the biosynthesis of plant fatty acids. BBA-Lipids Lipid Metab. 1996, 1301, 7-56. [CrossRef]

61. Joyard, J.; Douce, R. Galactolipid synthesis. In the Biochemistry of Plants; Lipids Stumpf, P.K., Ed.; Structure and Function; Academic Press: New York, NY, USA, 1987; pp. 215-274.

62. Bates, P.D.; Ohlrogge, J.B.; Pollard, M. Incorporation of newly synthesized fatty acids into cytosolic glycerolipids in pea leaves occurs via acyl editing. J. Biol. Chem. 2007, 282, 31206-31216. [CrossRef] [PubMed]

63. Roughan, P.G.; Ohlrogge, J.B. Evidence that isolated chloroplasts contain an integrated lipid-synthesizing assembly that channels acetate into long-chain fatty acids. Plant Physiol. 1996, 110, 1239-1247. [CrossRef] [PubMed]

64. Givan, C.V. The source of acetyl coenzyme A in chloroplasts of higher plants. Physiol. Plant 1983, 57, 311-316. [CrossRef]

65. Bao, X.; Focke, M.; Pollard, M.; Ohlrogge, J. Understanding in vivo carbon precursor supply for fatty acid synthesis in leaf tissue. Plant J. 2000, 22, 39-50. [CrossRef] [PubMed] 
66. Joyard, J.; Ferro, M.; Masselon, C.; Seigneurin-Berny, D.; Salvi, D.; Garin, J.; Rolland, N. Chloroplast proteomics highlights the subcellular compartmentation of lipid metabolism. Prog. Lipid Res. 2010, 49, 128-158. [CrossRef] [PubMed]

67. Rodríguez-Villalón, A.; Gas, E.; Rodríguez-Concepción, M. Phytoene synthase activity controls the biosynthesis of carotenoids and the supply of their metabolic precursors in dark-grown Arabidopsis seedlings. Plant J. 2009, 60, 424-435. [CrossRef] [PubMed]

68. Zbierzak, A.M.; Kanwischer, M.; Wille, C.; Vidi, P.A.; Giavalisco, P.; Lohmann, A.; Briesen, I.; Porfirova, S.; Bréhélin, C.; Kessler, F.; et al. Intersection of the tocopherol and plastoquinol metabolic pathways at the plastoglobule. Biochem. J. 2010, 425, 389-399. [CrossRef] [PubMed]

69. Sandoval, F.J.; Zhang, Y.; Roje, S. Flavin nucleotide metabolism in plants monofunctional enzymes synthesize FAD in plastids. J. Biol. Chem. 2008, 283, 30890-30900. [CrossRef] [PubMed]

70. Falk, J.; Munne-Bosch, S. Tocochromanol functions in plants: Antioxidation and beyond. J. Exp. Bot. 2010, 61, 1549-1566. [CrossRef] [PubMed]

71. Yamamizo, C.; Kishimoto, S.; Ohmiya, A. Carotenoid composition and carotenogenic gene expression during Ipomoea petal development. J. Exp. Bot. 2009, 61, 709-719. [CrossRef] [PubMed]

72. Havaux, M.; Niyogi, K.K. The violaxanthin cycle protects plants from photooxidative damage by more than one mechanism. Proc. Nat. Acad. Sci. USA 1999, 96, 8762-8767. [CrossRef] [PubMed]

73. Holt, N.E.; Zigmantas, D.; Valkunas, L.; Li, X.P.; Niyogi, K.K.; Fleming, G.R. Carotenoid cation formation and the regulation of photosynthetic light harvesting. Science 2005, 307, 433-436. [CrossRef] [PubMed]

74. Lokstein, H.; Tian, L.; Polle, J.E.; DellaPenna, D. Xanthophyll biosynthetic mutants of Arabidopsis thaliana: Altered nonphotochemical quenching of chlorophyll fluorescence is due to changes in photosystem II antenna size and stability. BBA-Bioenergetics 2002, 1553, 309-319. [CrossRef]

75. Pogson, B.J.; Niyogi, K.K.; Bjorkman, O.; DellaPenna, D. Altered xanthophyll compositions adversely affect chlorophyll accumulation and nonphotochemical quenching in Arabidopsis mutants. Proc. Nat. Acad. Sci. USA 1998, 95, 13324-13329. [CrossRef] [PubMed]

76. DellaPenna, D.; Pogson, B.J. Vitamin synthesis in plants: Tocopherols and carotenoids. Annu. Rev. Plant Biol. 2006, 57, 711-738. [CrossRef] [PubMed]

77. Carol, P.; Stevenson, D.; Bisanz, C.; Breitenbach, J.; Sandmann, G.; Mache, R.; Coupland, G.; Kuntz, M. Mutations in the Arabidopsis gene IMMUTANS cause a variegated phenotype by inactivating a chloroplast terminal oxidase associated with phytoene desaturation. Plant Cell 1999, 11, 57-68. [CrossRef] [PubMed]

78. Norris, S.R.; Barrette, T.R.; DellaPenna, D. Genetic dissection of carotenoid synthesis in Arabidopsis defines plastoquinone as an essential component of phytoene desaturation. Plant Cell 1995, 7, 2139-2149. [CrossRef] [PubMed]

79. Cunningham, F.X.; Gantt, E. Genes and enzymes of carotenoid biosynthesis in plants. Annu. Rev. Plant Biol. 1998, 49, 557-583. [CrossRef] [PubMed]

80. Pogson, B.; McDonald, K.A.; Truong, M.; Britton, G.; DellaPenna, D. Arabidopsis carotenoid mutants demonstrate that lutein is not essential for photosynthesis in higher plants. Plant Cell 1996, 8, 1627-1639. [CrossRef] [PubMed]

81. Grusack, M.A.; DellaPenna, D. Improving the nutrient composition of plants to enhance human nutrition and health. Annu. Rev. Plant Physiol. 1999, 50, 133-161. [CrossRef] [PubMed]

82. Kobayashi, N.; DellaPenna, D. Tocopherol metabolism, oxidation and recycling under high light stress in Arabidopsis. Plant J. 2008, 55, 607-618. [CrossRef] [PubMed]

83. Marin, E.; Nussaume, L.; Quesada, A.; Gonneau, M.; Sotta, B.; Hugueney, P.; Frey, A.; Marion-Poll, A. Molecular identification of zeaxanthin epoxidase of Nicotiana plumbaginifolia, a gene involved in abscisic acid biosynthesis and corresponding to the $A B A$ locus of Arabidopsis thaliana. EMBO J. 1996, 15, 2331. [PubMed]

84. Lange, T. Molecular biology of gibberellin synthesis. Planta 1998, 204, 409-419. [CrossRef] [PubMed]

85. Schwartz, S.H.; Zeevaart, J.A. Abscisic acid biosynthesis and metabolism. In Plant Hormones; Springer: Berlin/Heidelberger, Germany, 2010; pp. 137-155.

86. Eisenreich, W.; Bacher, A.; Arigoni, D.; Rohdich, F. Biosynthesis of isoprenoids via the non-mevalonate pathway. Cell. Mol. Life Sci. 2004, 61, 1401-1426. [CrossRef] [PubMed]

87. Rodriguez-Concepción, M.; Boronat, A. Elucidation of the methylerythritol phosphate pathway for isoprenoid biosynthesis in bacteria and plastids. A metabolic milestone achieved through genomics. Plant Physiol. 2002, 130, 1079-1089. [CrossRef] [PubMed] 
88. Nambara, E.; Marion-Poll, A. Abscisic acid biosynthesis and catabolism. Annu. Rev. Plant Biol. 2005, 56, 165-185. [CrossRef] [PubMed]

89. Lau, O.S.; Deng, X.W. Plant hormone signaling lightens up: Integrators of light and hormones. Curr. Opin. Plant Biol. 2010, 13, 571-577. [CrossRef] [PubMed]

90. Graebe, J.E. Gibberellin biosynthesis and control. Annu. Rev. Plant Physiol. 1987, 38, 419-465. [CrossRef]

91. Aach, H.; Bode, H.; Robinson, D.G.; Graebe, J.E. ent-Kaurene synthetase is located in proplastids of meristematic shoot tissues. Planta 1997, 202, 211-219. [CrossRef]

92. Helliwell, C.A.; Sullivan, J.A.; Mould, R.M.; Gray, J.C.; Peacock, W.J.; Dennis, E.S. A plastid envelope location of Arabidopsis ent-kaurene oxidase links the plastid and endoplasmic reticulum steps of the gibberellin biosynthesis pathway. Plant J. 2001, 28, 201-208. [CrossRef] [PubMed]

93. Sun, T.P.; Kamiya, Y. Regulation and cellular localization of ent-kaurene synthesis. Physiol. Plant 1997, 101, 701-708. [CrossRef]

94. Nelson, D.R.; Schuler, M.A.; Paquette, S.M.; Werck-Reichhart, D.; Bak, S. Comparative genomics of rice and Arabidopsis. Analysis of 727 cytochrome P450 genes and pseudogenes from a monocot and a dicot. Plant Physiol. 2004, 135, 756-772. [CrossRef] [PubMed]

95. Croteau, R.; Kutchan, T.M.; Lewis, N.G. Natural products (secondary metabolites). In Biochemistry $\mathcal{E}$ Molecular Biology of Plants; Buchanan, B., Gruissem, W., Jones, R.L., Eds.; American Society of Plant Physiologists: Beltsville, MD, USA, 2000; pp. 1250-1318.

96. Darko, E.; Heydarizadeh, P.; Schoefs, B.; Sabzalian, M.R. Photosynthesis under artificial light: The shift in primary and secondary metabolism. Phil. Trans. R Soc. B 2014, 369, 20130243. [CrossRef] [PubMed]

97. Carvalho, S.D.; Folta, K.M. Environmentally modified organisms-expanding genetic potential with light. Crit. Rev. Plant Sci. 2014, 33, 486-508. [CrossRef]

98. Kopsell, D.A.; Sams, C.E. Increases in shoot tissue pigments, glucosinolates, and mineral elements in sprouting broccoli after exposure to short-duration blue light from light emitting diodes. J. Am. Soc. Hortic. Sci. 2013, 138, 31-37.

99. Folta, K.M.; Childers, K.S. Light as a growth regulator: Controlling plant biology with narrow-bandwidth solid-state lighting systems. HortScience 2008, 43, 1957-1964.

100. Chen, M.; Chory, J.; Fankhauser, C. Light signal transduction in higher plants. Annu. Rev. Genet. 2004, 38, 87-117. [CrossRef] [PubMed]

101. Ouzounis, T.; Fretté, X.; Ottosen, C.O.; Rosenqvist, E. Spectral effects of LEDs on chlorophyll fluorescence and pigmentation in Phalaenopsis 'Vivien' and 'Purple Star'. Physiol. Plant 2015, 154, 314-327. [CrossRef] [PubMed]

102. Vergeer, L.H.T.; Aarts, T.L.; Degroot, J.D. The wasting disease and the effect of abiotic factors (light-intensity, temperature, salinity) and infection with Labyrinthula-zosterae on the phenolics content of Zostera-marina shoots. Aquat. Bot. 1995, 52, 35-44. [CrossRef]

103. Giliberto, L.; Perrotta, G.; Pallara, P.; Weller, J.L.; Fraser, P.D.; Bramley, P.M.; Fiore, A.; Tavazza, M.; Giuliano, G. Manipulation of the blue light photoreceptor cryptochrome 2 in tomato affects vegetative development, flowering time, and fruit antioxidant content. Plant Physiol. 2005, 137, 199-208. [CrossRef] [PubMed]

104. Kataoka, I.; Sugiyama, A.; Beppu, K. Role of ultraviolet radiation in accumulation of anthocyanin in berries of 'Gros Colman' grapes (Vitis vinifera L.). J. Jpn. Soc. Hort. Sci. 2003, 72, 1-6. [CrossRef]

105. Tsormpatsidis, E.; Henbest, R.G.C.; Davis, F.J.; Battey, N.H.; Hadley, P.; Wagstaffe, A. UV irradiance as a major influence on growth, development and secondary products of commercial importance in Lollo Rosso lettuce 'Revolution' grown under polyethylene films. Environ. Exp. Bot. 2008, 63, 232-239. [CrossRef]

106. Zhou, Y.; Singh, B.R. Red light stimulates flowering and anthocyanin biosynthesis in American cranberry. Plant Growth Regul. 2002, 38, 165-171. [CrossRef]

107. Ramalho, J.C.; Marques, N.C.; Semedo, J.N.; Matos, M.C.; Quartin, V.L. Photosynthetic performance and pigment composition of leaves from two tropical species is determined by light quality. Plant Biol. 2002, 4, 112-120. [CrossRef]

108. Furuya, M. Phytochromes: Their molecular species, gene families, and functions. Annu. Rev. Plant Physiol. 1993, 44, 617-645. [CrossRef]

109. Dougher, T.A.; Bugbee, B.G. Is blue light good or bad for plants? Life Support Biosphere Sci. 1998, 5, $129-136$. 
110. Schuerger, A.C.; Brown, C.S.; Stryjewski, E.C. Anatomical features of pepper plants (Capsicum annuum L.) grown under red light-emitting diodes supplemented with blue or far-red light. Ann. Bot. Lond. 1997, 79, 273-282. [CrossRef] [PubMed]

111. Heo, J.; Lee, C.; Chakrabarty, D.; Paek, K. Growth responses of marigold and salvia bedding plants as affected by monochromic or mixture radiation provided by a light-emitting diode (LED). Plant Growth Regul. 2002, 38, 225-230. [CrossRef]

112. Folta, K.M.; Koss, L.L.; McMorrow, R.; Kim, H.H.; Kenitz, J.D.; Wheeler, R.; Sager, J.C. Design and fabrication of adjustable red-green-blue LED light arrays for plant research. BMC Plant Biol. 2005, 5, 17.

113. Zhang, H.; Xu, Z.; Cui, J.; Guo, Y.; Gu, A. Effects of different spectra on growth and nutritious quality of radish sprouting seedlings. China Veg. 2009, 10, 28-32.

114. Zhang, L.W.; Liu, S.Q.; Zhang, Z.K.; Yang, R.; Yang, X.J. Effects of light qualities on the nutritive quality of radish sprouts. Acta. Nutr. Sin. 2010, 4, 26.

115. Chang, T.T.; Liu, X.Y.; Xu, Z.G.; Yang, Y. Effects of light spectral energy distribution on growth and development of tomato seedlings. Sci. Agric. Sin. 2010, 8, 27-35.

116. Li, S.; Pan, R. Effect of blue light on the metabolism of carbohydrate and protein in rice (Oryza sativa L.) seedlings. Acta Phytophysiol. Sin. 1995, 21, 22-28.

117. Lefsrud, M.G.; Kopsell, D.A.; Sams, C.E. Irradiance from distinct wavelength light-emitting diodes affect secondary metabolites in kale. HortScience 2008, 43, 2243-2244.

118. Briggs, W.R.; Huala, E. Blue-light photoreceptors in higher plants. Annu. Rev. Cell Biol. 1999, 15, 33-62. [CrossRef] [PubMed]

119. Tla1ka, M.; Runquist, M.; Fricker, M. Light perception and the role of the xanthophyll cycle in blue-lightdependent chloroplast movements in Lemna trisulca L. Plant J. 1999, 20, 447-459. [CrossRef]

120. Felker, F.C.; Doehlert, D.C.; Eskins, K. Effects of red and blue light on the composition and morphology of maize kernels grown in vitro. Plant Cell Tissue Org. 1995, 42, 147-152. [CrossRef]

121. Hultberg, M.; Jönsson, H.L.; Bergstrand, K.J.; Carlsson, A.S. Impact of light quality on biomass production and fatty acid content in the microalga Chlorella vulgaris. Bioresour. Technol. 2014, 159, 465-467. [CrossRef] [PubMed]

122. Hugly, S.; Somerville, C. A role for membrane lipid polyunsaturation in chloroplast biogenesis at low temperature. Plant Physiol. 1992, 99, 197-202. [CrossRef] [PubMed]

123. Jung, E.S.; Lee, S.; Lim, S.H.; Ha, S.H.; Liu, K.H.; Lee, C.H. Metabolite profiling of the short-term responses of rice leaves (Oryza sativa cv. Ilmi) cultivated under different LED lights and its correlations with antioxidant activities. Plant Sci. 2013, 210, 61-69. [CrossRef] [PubMed]

124. Kusano, M.; Tohge, T.; Fukushima, A.; Kobayashi, M.; Hayashi, N.; Otsuki, H.; Kondou, Y.; Goto, H.; Kawashima, M.; Matsuda, F.; et al. Metabolomics reveals comprehensive reprogramming involving two independent metabolic responses of Arabidopsis to UV-B light. Plant J. 2011, 67, 354-369. [CrossRef] [PubMed]

125. Neff, M.M.; Street, I.H.; Turk, E.M.; Ward, J.M. Interaction of light and hormone signaling to mediate photomorphogenesis. In Photomorphogenesis in Plants and Bacteria-Function and Signal Transduction Mechanisms; Schafer, E., Nagy, F., Eds.; Springer: Dordrecht, The Netherlands, 2005; pp. 441-445.

126. Alabadi, D.; Gil, J.; Blazquez, M.A.; Garcia-Martinez, J.L. Gibberellins repress photomorphogenesis in darkness. Plant Physiol. 2004, 134, 1050-1057. [CrossRef] [PubMed]

127. Shinomura, T.; Nagatani, A.; Chory, J.; Furuya, M. The induction of seed germination in Arabidopsis thaliana is regulated principally by phytochrome B and secondarily by phytochrome A. Plant Physiol. 1994, 104, 363-371. [CrossRef] [PubMed]

128. Oh, E.; Yamaguchi, S.; Kamiya, Y.; Bae, G.; Chung, W.I.; Choi, G. Light activates the degradation of PIL5 protein to promote seed germination through gibberellin in Arabidopsis. Plant J. 2006, 47, 124-139. [CrossRef] [PubMed]

129. Seo, M.; Hanada, A.; Kuwahara, A.; Endo, A.; Okamoto, M.; Yamauchi, Y.; North, H.; Marion-Poll, A.; Sun, T.P.; Koshiba, T.; et al. Regulation of hormone metabolism in Arabidopsis seeds: Phytochrome regulation of abscisic acid metabolism and abscisic acid regulation of gibberellin metabolism. Plant J. 2006, 48, 354-366. [CrossRef] [PubMed] 
130. Yamauchi, Y.; Takeda-Kamiya, N.; Hanada, A.; Ogawa, M.; Kuwahara, A.; Seo, M.; Kamiya, Y.; Yamaguchi, S. Contribution of gibberellin deactivation by AtGA2ox2 to the suppression of germination of dark-imbibed Arabidopsis thaliana seeds. Plant Cell Physiol. 2007, 48, 555-561. [CrossRef] [PubMed]

131. Zhao, X.Y.; Yu, X.H.; Foo, E.; Symons, G.M.; Lopez, J.; Bendehakkalu, K.T.; Xiang, J.; Weller, J.L.; Liu, X.M.; Reid, J.B.; et al. A study of gibberellin homeostasis and cryptochrome-mediated blue light inhibition of hypocotyl elongation. Plant Physiol. 2007, 145, 106-118. [CrossRef] [PubMed]

132. Yamaguchi, S. Gibberellin metabolism and its regulation. Annu. Rev. Plant Biol. 2008, 59, 225-251. [CrossRef] [PubMed]

133. Bräutigam, K.; Dietzel, L.; Kleine, T.; Ströher, E.; Wormuth, D.; Dietz, K.J.; Radke, D.; Wirtz, M.; Hell, R.; Dörmann, P.; Nunes-Nesi, A.; Schauer, N.; Fernie, A.R.; et al. Dynamic plastid redox signals integrate gene expression and metabolism to induce distinct metabolic states in photosynthetic acclimation in Arabidopsis. Plant Cell 2009, 21, 2715-2732. [CrossRef] [PubMed]

134. Wulff-Zottele, C.; Gatzke, N.; Kopka, J.; Orellana, A.; Hoefgen, R.; Fisahn, J.; Hesse, H. Photosynthesis and metabolism interact during acclimation of Arabidopsis thaliana to high irradiance and sulphur depletion. Plant Cell Environ. 2010, 33, 1974-1988. [CrossRef] [PubMed]

135. Caldana, C.; Degenkolbe, T.; Cuadros-Inostroza, A.; Klie, S.; Sulpice, R.; Leisse, A.; Steinhauser, D.; Fernie, A.R.; Willmitzer, L.; Hannah, M.A. High-density kinetic analysis of the metabolomics and transcriptomic response of Arabidopsis to eight environmental conditions. Plant J. 2011, 67, 869-884. [CrossRef] [PubMed]

136. Allen, D.J.; McKee, I.F.; Farage, P.K.; Baker, N.R. Analysis of limitations to $\mathrm{CO}_{2}$ assimilation on exposure of leaves of two Brassica napus cultivars to UV-B. Plant Cell Physiol. 1997, 20, 633-640. [CrossRef]

137. Allen, D.J.; Nogués, S.; Baker, N.R. Ozone depletion and increased UV-B radiation: Is there a real threat to photosynthesis? J. Exp. Bot. 1998, 49, 1775-1788.

138. Nogués, S.; Baker, N.R. Evaluation of the role of damage to photosystem II in the inhibition of $\mathrm{CO}_{2}$ assimilation in pea leaves on exposure to UV-B radiation. Plant Cell Environ. 1995, 18, 781-787. [CrossRef]

139. Nogués, S.; Allen, D.J.; Morison, J.I.; Baker, N.R. Characterization of stomatal closure caused by ultraviolet-B radiation. Plant Physiol. 1999, 121, 489-496. [CrossRef] [PubMed]

140. Tripathy, B.C.; Brown, C.S. Root-shoot interaction in the greening of wheat seedlings grown under red light. Plant Physiol. 1995, 107, 407-411. [CrossRef] [PubMed]

141. Yang, Z.Y.; Kobayashi, E.; Katsuno, T.; Asanuma, T.; Fujimori, T.; Ishikawa, T.; Tomomura, M.; Mochizuki, K.; Watase, T.; Nakamura, Y.; et al. Characterisation of volatile and non-volatile metabolites in etiolated leaves of tea (Camellia sinensis) plants in the dark. Food Chem. 2012, 135, 2268-2276. [CrossRef] [PubMed]

142. Brillouet, J.M.; Romieu, C.; Schoefs, B.; Solymosi, K.; Cheynier, V.; Fulcrand, H.; Verdeil, J.L.; Conéjéro, G. The tannosome is an organelle forming condensed tannins in the chlorophyllous organs of Tracheophyta. Ann. Bot. 2013, 112, 1003-1014. [CrossRef] [PubMed]

143. Chen, Y.Y.; Fu, X.M.; Mei, X.; Zhou, Y.; Cheng, S.H.; Zeng, L.T.; Dong, F.; Yang, Z.Y. Proteolysis of chloroplast proteins is responsible for accumulation of free amino acids in dark-treated tea (Camellia sinensis) leaves. J. Proteom. 2017, 157, 10-17. [CrossRef] [PubMed]

144. Wardlaw, I.F.; Marshall, C. Assimilate movement in Lolium and Sorghum leaves. II. Irradiance effects on the products of photosynthesis. Funct. Plant Biol. 1976, 3, 389-400.

145. Sharkey, T.D.; Berry, J.A.; Raschke, K. Starch and sucrose synthesis in Phaseolus vulgaris as affected by light, $\mathrm{CO}_{2}$, and abscisic acid. Plant Physiol. 1985, 77, 617-620. [CrossRef] [PubMed]

146. Britz, S.J.; Sager, J.C. Photomorphogenesis and photoassimilation in soybean and sorghum grown under broad spectrum or blue-deficient light sources. Plant Physiol. 1990, 94, 448-454. [CrossRef] [PubMed]

147. Niyogi, K.K.; Shih, C.; Chow, W.S.; Pogson, B.J.; DellaPenna, D.; Björkman, O. Photoprotection in a zeaxanthin-and lutein-deficient double mutant of Arabidopsis. Photosynth. Res. 2001, 67, 139-145. [CrossRef] [PubMed]

(C) 2018 by the authors. Licensee MDPI, Basel, Switzerland. This article is an open access article distributed under the terms and conditions of the Creative Commons Attribution (CC BY) license (http:/ / creativecommons.org/licenses/by/4.0/). 